\title{
KERJASAMA PUSAT KEGIATAN BELAJAR MASYARAKAT DENGAN PEMERINTAH DESA SEBAGAI UPAYA MENINGKATKAN PARTISIPASI PENDIDIKAN MASYARAKAT
}

\author{
COOPERATION WITH THE VILLAGE GOVERNMENT AS AN EFFORT TO \\ INCREASE COMMUNITY EDUCATION PARTICIPATION
}

\begin{tabular}{c} 
Webri Widiyantoro* \\
Program Studi Magister Pendidikan Pancasila dan Kewarganegaraan Universitas Negeri Malang \\
Jalan Semarang Nomor 5 Malang 65145, Indonesia \\
\hline
\end{tabular}

\section{INFO ARTIKEL}

\section{Riwayat Artikel: \\ Diterima : 03 Desember 2020 \\ Disetujui : 01 Juni 2021}

\section{Keywords:}

cooperation, community learning activity center, village government, community education participation

\section{Kata Kunci:}

kerjasama, pusat kegiatan belajar masyarakat, pemerintah desa, partisipasi pendidikan masyarakat

\section{*) Korespondensi:}

E-mail: webriwidiyantoro873@ gmail.com
Abstract: this study aimed to analyze educational strategies and patterns of cooperation between community learning activity centers and village governments, and analyze the constraints and efforts made in the process of increasing community education participation. The study used a qualitative approach with a case study method. The cases were chosen were typical cases that be able to represent similar cases, namely a form of collaboration between the community learning activity center and the village government. The qualitative data analysis used was pattern matchmaking analysis, to answer big questions related to strategies, forms, constraints, and solutions in building cooperation between community learning activity centers and village governments. The obtained results indicated that the strategies used by the community learning activity center in the process of increasing community education participation were in the form of community identification strategies, programs, and partnerships. The pattern of cooperation between the community learning center and the village government was in the form of coaching and mentoring, with the form of cooperation in the form of support for policy regulations, legal protection, budget assistance, mentoring, coaching, and motivation. The obstacles faced by the community learning activity center were weak community commitment and less than optimal program socialization. Efforts to overcome these obstacles were carried out by implementing performance and performance strategies and increasing innovation in disseminating educational programs.

\begin{abstract}
Abstrak: kajian ini bertujuan untuk menganalisis strategi pendidikan dan pola kerjasama antara pusat kegiatan belajar masyarakat dengan pemerintah desa, serta menganalisis kendala dan upaya yang dilakukan dalam proses meningkatkan partisipasi pendidikan masyarakat. Pendekatan penelitian yang digunakan yaitu pendekatan kualitatif dengan metode studi kasus. Kasus yang dipilih merupakan kasus tipikal yang mampu menjadi representatif dari kasus sejenis yaitu bentuk kerjasama antara pusat kegiatan belajar masyarakat dengan pemerintah desa. Analisis data kualitatif yang digunakan yaitu analisis penjodohan pola, untuk menjawab pertanyaan besar terkait strategi, bentuk, kendala, dan solusi dalam membangun kerjasama antara pusat kegiatan belajar masyarakat dengan pemerintah desa. Hasil yang diperoleh menunjukkan bahwa strategi yang digunakan oleh pusat kegiatan belajar masyarakat dalam proses meningkatkan partisipasi pendidikan masyarakat berupa strategi identifikasi
\end{abstract}


masyarakat, program, dan kemitraan. Pola kerjasama antara pusat kegiatan belajar masyarakat dan pemerintah desa berupa pembinaan dan pendampingan, dengan bentuk kerjasama berupa dukungan regulasi kebijakan, perlindungan hukum, bantuan anggaran, pendampingan, pembinaan, dan motivasi. Kendala yang dihadapi oleh pusat kegiatan belajar masyarakat yaitu lemahnya komitmen masyarakat dan sosialisasi program yang kurang optimal. Upaya untuk mengatasi kendala tersebut dilakukan dengan menerapkan strategi unjuk kerja dan kinerja, serta meningkatkan inovasi dalam melakukan sosialisasi program pendidikan.

\section{PENDAHULUAN}

Pembangunan ekonomi, politik, sosial, budaya, pertahanan dan keamanan negara tidak terlepas dari pembangunan sumber daya manusia (SDM) yang dimiliki oleh suatu bangsa. Pembangunan SDM tersebut berkaitan dengan visi lembaga pendidikan yaitu mewujudkan pembelajaran sepanjang hayat sebagai konsep belajar yang berkesinambungan. Lembaga pendidikan menurut Marzuki (2009) memiliki fungsi sebagai partner masyarakat terutama dalam mempengaruhi corak pengalaman, literasi, dan kondisi sosial ekonomi. Pendidikan memungkinkan seseorang untuk mengembangkan potensi-potensi yang dimiliki sesuai dengan kebutuhan hidupnya, sehingga mampu menunjang dalam pembangunan bangsa dan negara.

Luaran (output) dari pendidikan dapat dilihat dalam jangka waktu yang lebih panjang apabila dibandingkan dengan pembangunan di bidang lainnya. Hal tersebut mempengaruhi pola pikir masyarakat terkait kurang pentingnya ketuntasan pendidikan karena dianggap tidak berpengaruh pada tingkat kesejahteraan. Berdasarkan data yang dihimpun oleh pemerintah desa, persentase ketuntasan pendidikan formal masyarakat cukup rendah. Pada 6 Maret 2018, jumlah penduduk yang tidak tamat Sekolah Dasar (SD) sebanyak $10,03 \%$, tamatan Sekolah Dasar (SD) sebanyak 26,61\%, tamatan Sekolah Menengah Pertama (SMP) sebanyak 20,73\%, tamatan Sekolah Menengah Atas (SMA) sebanyak 21,84\%, tamatan diploma $1,36 \%$, tamatan sarjana $3,40 \%$, dan sisanya tidak atau belum sekolah. Eksistensi lembaga pendidikan di mata masyarakat desa dianggap tidak penting karena output yang dihasilkan tidak berbanding lurus dengan pembangunan ekonomi keluarga. Besarnya angka penduduk yang tidak menuntaskan pendidikan sepanjang hayat menurut Syamsuri dan Ulfah (2019) disebabkan oleh faktor ekonomi. Anak- anak yang berasal dari keluarga miskin harus merelakan untuk berhenti sekolah karena membantu keluarga bekerja guna memperoleh penghasilan. Masyarakat ingin memperoleh hasil yang lebih cepat untuk menuntaskan kemiskinan, sedangkan pendidikan tidak mampu mewujudkan keinginan tersebut sehingga sekolah formal dianggap tidak dapat menjawab permasalahan kehidupan masyarakat di desa.

Setiap orang berhak untuk memperoleh pendidikan baik pendidikan formal melalui sekolah maupun pendidikan nonformal. Sekolah menurut Marzuki (2009) merupakan partner masyarakat yang bertanggung jawab atas perubahan corak sudut pandang, pengalaman, sekaligus kondisi sosial dan ekonomi masyarakat. Kebutuhan masyarakat terhadap layanan pendidikan nonformal menurut Direktorat Pembinaan Pendidikan Masyarakat (2012) semakin berkembang mengikuti perubahan zaman. Pelayanan pendidikan nonformal di desa salah satunya diwujudkan dalam bentuk Pusat Kegiatan Belajar Masyarakat (PKBM) yang dibentuk untuk menjawab kebutuhan masyarakat. Konsep pendidikan nonformal berdasarkan BAN PAUD \& PNF (2019) bersifat jangka pendek berupa kemampuan fungsional untuk kepentingan masa kini atau masa depan dengan menekankan pada kompetensi yang dihasilkan. PKBM sebagai salah satu wujud pendidikan nonformal didirikan untuk membantu meningkatkan kondisi ekonomi masyarakat serta memberantas buta huruf dan anak putus sekolah. Tujuan khusus didirikannya PKBM yaitu untuk memandirikan masyarakat, membentuk kelompok usaha, dan meningkatkan kesejahteraan masyarakat desa. Program yang diselenggarakan adalah paket kesetaraan, pendidikan kewirausahaan, serta taman bacaan masyarakat. PKBM menurut Kamil (2010) merupakan lembaga pendidikan yang diselenggarakan di luar sistem pendidikan 
formal yang dikelola oleh masyarakat itu sendiri. PKBM memberikan kesempatan kepada masyarakat untuk mengembangkan berbagai model pembelajaran dengan tujuan mengembangkan kemampuan dan keterampilan guna meningkatkan kualitas hidup masyarakat. Tujuan penting dalam pengembangan PKBM menurut Sudjana (2001) ada tiga, diantaranya yaitu: (a) memberdayakan masyarakat agar mampu mandiri berdaya, (b) meningkatkan kualitas hidup masyarakat baik sosial maupun ekonomi, dan (c) meningkatkan kepekaan dan mengasah keterampilan memecahkan masalah terhadap permasalahan lingkungan sekitar.

PKBM sebagai tempat pembelajaran dan sumber informasi bagi masyarakat yang dibentuk dan dikelola oleh masyarakat sendiri, maka perlu dilakukan kerjasama dengan pemerintah desa untuk memperkuat tujuan pendidikan di satuan PKBM. Kemitraan tersebut dimaksudkan agar desa sebagai lembaga pemerintah turut berperan dalam terciptanya tingkat partisipasi masyarakat dalam mewujudkan tujuan pendidikan. Dasar partisipasi masyarakat dalam pendidikan menurut Ardilah, Makmur, dan Hanafi (2002) dapat diwujudkan melalui dorongan tokoh masyarakat kepada para orang tua untuk menyekolahkan anaknya. Keberhasilan kerjasama dalam membentuk partisipasi masyarakat sebagaimana dijelaskan oleh Direktorat Pembinaan Pendidikan Masyarakat (2012) didasarkan pada beberapa hal yaitu: (a) kualitas program yang ada di dalam PKBM harus menguntungkan bagi warga belajar, lembaga pendidikan, serta lembaga pemerintah, (b) tingkat keinovatifan program yang dirancang dalam kerjasama sejalan dengan kebutuhan masyarakat, dan (c) hasil luaran lulusan dari PKBM dapat bekerja dan memiliki skill yang mampu bersaing di berbagai bidang.

Berdasarkan permasalahan korelasi antara tingkat pendidikan dan ekonomi yang dihadapi oleh masyarakat di desa, kerjasama antara PKBM dan pemerintah desa menjadi prioritas utama dalam pendidikan non formal. Salah satu wujud kerjasama yang dilakukan oleh pemerintah desa dengan PKBM berdasarkan pendapat Syamsuri dan Ulfah (2019) yaitu berupa penyediaan fasilitas sarana dan prasarana di PKBM. Bentuk kemitraan yang dibangun oleh pendidikan nonformal masyarakat menurut Oktiwanti et al. (2016) dapat berupa desa binaan dan meluncurkan gagasan desa mandiri dengan pemberian instalasi listrik secara gratis bagi masyarakat pra-sejahtera. Adanya PKBM menurut Saputra (2017) dapat menstimulasi tokoh masyarakat untuk turut berpartisipasi dalam pelaksanaan program PKBM. Partisipasi yang diberikan oleh tokoh masyarakat tersebut diwujudkan dalam bentuk motivasi kepada warga melalui pendekatan spiritual, sehingga mampu membantu memobilisasi massa. PKBM menurut Rizka dan Suharyani (2015) sebagian besar menjalin kemitraan dengan instansi pemerintahan yang bersifat insidental dan kerjasama tersebut tidak bersifat jangka panjang. Strategi yang digunakan oleh PKBM dalam meningkatkan kecakapan hidup masyarakat menurut Irwan et al. (2016) ditunjukkan dengan melibatkan tokoh masyarakat, dengan demikian PKBM dapat mengadakan kerjasama baik perorangan maupun kerjasama lembaga dari eksternal pengelola.

Berdasarkan analisis awal terkait permasalahan tingkat pendidikan masyarakat desa, timbul permasalahan yang menarik untuk diteliti yaitu terkait kerjasama yang dilakukan oleh PKBM dengan pemerintah desa dalam upaya meningkatkan partisipasi pendidikan masyarakat. Hal tersebut dikarenakan beberapa ahli tidak menjabarkan secara mendetail dan sistematis mengenai program kerjasama yang dilakukan oleh PKBM. Oleh karena itu dalam artikel ini membahas beberapa rumusan masalah, yaitu: (1) strategi pendidikan yang dilaksanakan oleh PKBM, (2) pola kerjasama PKBM dengan pemerintah desa sebagai upaya meningkatkan partisipasi pendidikan masyarakat, (3) kendala yang dihadapi oleh PKBM dan pemerintah desa dalam meningkatkan partisipasi pendidikan masyarakat, dan (4) upaya PKBM dan pemerintah desa untuk mengatasi kendala dalam meningkatkan partisipasi pendidikan masyarakat.

\section{METODE}

Kajian ini menggunakan pendekatan kualitatif dengan metode studi kasus tunggal untuk mengeksplorasi sebuah sistem yang terbatas melalui pengumpulan data yang rinci dan mendalam. Kasus yang dipilih merupakan kasus tipikal sebagai representatif dari kasus sejenis yaitu tentang kerjasama pusat kegiatan belajar masyarakat dengan pemerintah desa sebagai upaya meningkatkan partisipasi pendidikan masyarakat. Sumber data primer 
yang digunakan yaitu key informant yang terdiri dari Ketua PKBM Sultan Agung, Kepala Desa Jatiguwi, Kepala Dusun Jatiguwi, tutor PKBM, dan warga belajar PKBM. Data sekunder yaitu soft data yang berupa observasi dan dokumentasi dari segala bentuk kerjasama PKBM dengan pemerintah desa sebagai upaya meningkatkan partisipasi pendidikan masyarakat desa Jatiguwi Sumberpucung. Pengumpulan data dilakukan dengan wawancara semi terstruktur, sehingga memudahkan dalam mengembangkan pertanyaan. Pengumpulan data juga dilakukan melalui kegiatan observasi partisipan dan dokumentasi. Teknik analisis data yang digunakan yaitu teknik analisis data kualitatif Robert $\mathrm{K}$. Yin yang berupa teknik penjodohan pola (Yin, 2006). Data yang telah terkumpul selanjutnya diklarifikasi untuk menjawab rumusan masalah, kemudian ditarik kesimpulan sebagai bentuk penyederhanaan temuan berdasarkan rumusan masalah yang telah disusun.

\section{HASIL DAN PEMBAHASAN}

\section{Strategi Pendidikan yang Dilaksanakan oleh PKBM}

PKBM adalah sebuah lembaga pendidikan nonformal yang bertujuan untuk membantu masyarakat dalam proses peningkatan taraf ekonomi masyarakat melalui pengembangan pengetahuan, sikap, dan keterampilan yang bersifat aplikatif. PKBM menurut Irwan et al. (2016) berperan dalam peningkatan kecakapan hidup masyarakat untuk menjawab permasalahan dan kebutuhan masyarakat itu sendiri. PKBM harus mendesain pembelajaran yang bersifat aplikatif, sehingga secara fungsional dapat digunakan dalam jangka waktu yang lebih pendek. Salah satu program yang dilaksanakan yaitu paket kesetaraan $\mathrm{A}, \mathrm{B}$, dan $\mathrm{C}$ sebagai sarana bagi masyarakat yang tidak berkesempatan mendapatkan pendidikan formal. Program pendidikan kewirausahaan juga turut dilaksanakan untuk menjawab permasalahan masyarakat desa yang menganggap tingkat pendidikan tidak memiliki korelasi dengan tingkat perekonomian. Pendidikan kewirausahaan bertujuan untuk mengatasi permasalahan kemiskinan dan mendukung masyarakat mandiri secara ekonomi. Program lainnya yaitu berupa Taman Bacaan Masyarakat (TBM) yang memfasilitasi seluruh masyarakat desa untuk meningkatkan literasi.
PKBM juga mendesain program pelestarian budaya dengan tujuan untuk mempertahankan kearifan lokal.

Strategi yang dilakukan PKBM untuk mewujudkan tujuan pendidikan dilakukan melalui beberapa upaya yaitu: (a) mengidentifikasi masyarakat desa terkait adanya pola pikir bahwa rendahnya kesadaran pendidikan masyarakat tidak memiliki korelasi dengan tingkat kesejahteraan, (b) merancang program pendidikan yang sesuai dengan analisis kebutuhan masyarakat, (c) membangun kemitraan dengan pemerintah desa, dan (d) melakukan monitoring dan evaluasi program. Strategi yang dapat dilakukan menurut pendapat Septiani (2015) ada delapan yaitu identifikasi masyarakat, strategi program, menyediakan sumber daya potensial, membangun kemitraan, monitoring, pendidikan alternatif, membangun pusat informasi, serta pengembangan masyarakat. PKBM memulai strategi pendidikan dengan mengidentifikasi kebutuhan masyarakat desa. Identifikasi tersebut menunjukkan bahwa masyarakat dengan tingkat ekonomi menengah ke bawah lebih memilih putus sekolah formal karena dengan bersekolah tidak dapat menjamin kesejahteraan ekonomi. Hasil identifikasi kebutuhan masyarakat menurut Kaufman dan Mayer (2013) dapat membantu PKBM untuk mengidentifikasi kesenjangan antara keadaan yang diharapkan dengan kenyataan yang terjadi, serta prioritas yang harus dilakukan oleh PKBM untuk mengatasi kesenjangan tersebut. Hasil identifikasi tersebut dijadikan sebagai analisis awal untuk membuat program pendidikan. Program yang didesain oleh PKBM berupa program kesetaraan, pendidikan kewirausahaan, taman bacaan masyarakat, dan pelestarian kebudayaan. Hal tersebut sejalan dengan pendapat Ibrahim et al. (2018) bahwa PKBM mampu merancang program kesetaraan, membuka taman bacaan, serta kegiatan wirausaha untuk kelompok masyarakat miskin guna meningkatkan taraf hidupnya. Hal tersebut menunjukkan bahwa setiap PKBM memiliki program yang berbeda sesuai dengan hasil identifikasi masyarakat.

Kemitraan yang dijalankan berupa kerjasama dengan pemerintah desa sebagai stakeholder yang mampu mempengaruhi partisipasi masyarakat untuk menuntaskan pendidikannya. Upaya meningkatkan partisipasi masyarakat dalam pendidikan dapat dilakukan oleh PKBM dengan 
cara menghimpun dukungan dari tokoh masyarakat, baik tokoh agama, pemerintahan, maupun dari kalangan akademisi (Saputra \& Hati, 2017). Faktor pendukung pengembangan program PKBM sebagaimana dijelaskan oleh Rizka dan Gustiana (2015) yaitu adanya manajemen program yang baik dalam melaksanakan kemitraan dengan pihak eksternal. PKBM harus mampu memaksimalkan manajemen tersebut dengan melakukan monitoring dan evaluasi guna keberlanjutan program dalam jangka panjang.

\section{Pola Kerjasama PKBM dengan Pemerintah Desa sebagai Upaya Meningkatkan Partisipasi Pendidikan Masyarakat}

Eksistensi PKBM tidak dapat terlepas dari jalinan kemitraan karena bantuan sumber daya dari pihak eksternal mampu mendorong perkembangan program lembaga. Kemitraan menurut Gunartin et al. (2018) dianggap sangat penting untuk menjalankan strategi pengembangan PKBM. Pengembangan kerjasama tersebut bertujuan untuk mencapai target keberhasilan program yang berkelanjutan. Program PKBM yang berkelanjutan membutuhkan dukungan dari pihak mitra dalam mengatasi masalah-masalah yang muncul sehingga akan berdampak pada produktivitas lembaga (Rizka \& Gustiana, 2015). Pola kerjasama yang diberikan oleh pemerintah desa kepada PKBM berupa pembinaan dan pendampingan. Dukungan regulasi kebijakan dan perlindungan hukum bersifat insidental, sedangkan pendampingan, pembinaan, dan motivasi oleh stakeholder bersifat longitudinal. Bentuk kerjasama yang bersifat longitudinal dapat meningkatkan partisipasi masyarakat dalam program PKBM. Kenaikan angka warga belajar dalam kurun waktu satu semester mencapai $26,9 \%$. Sejalan dengan hal tersebut Rizka dan Suharyani (2015) menyebutkan bahwa pola pengembangan kemitraan yang melibatkan stakeholder dapat meningkatkan sustainabilitas program pendidikan non formal.

Alur kerjasama dimulai dari akad, pelaksanaan program, dan monitoring. Akad kerjasama merupakan kegiatan yang sangat penting untuk menandakan bahwa ada hubungan timbal balik yang saling menguntungkan antara PKBM dengan pemerintah desa. Akad kerjasama ditulis dalam sebuah dokumen resmi yang ditandatangani oleh kedua belah pihak. Pihak pertama adalah PKBM yang ditandatangani oleh kepala PKBM. Pihak kedua adalah pemerintah desa yang ditandatangani oleh kepala desa. Langkah kerjasama sebagaimana diungkapkan Kamil (2010) yang pertama adalah penandatanganan akad kerjasama atau nota kesepahaman atau sering disebut Memorandum of Understanding (MoU). Penggunaan nota kesepahaman atau MoU tersebut bertujuan untuk menunjang komitmen dan profesionalitas dari kedua belah pihak. Pelaksanaan kerjasama didasarkan pada substansi akad kerjasama yang berpedoman pada pola kerjasama yaitu pembinaan dan pendampingan. Pemerintah desa memberikan dukungan regulasi kebijakan dan perlindungan hukum bagi PKBM, serta menjamin legalitas dan pemberian akses yang luas kepada PKBM untuk memberikan pelayanan masyarakat khususnya di bidang pendidikan. Kerjasama antara PKBM dan pemerintah menurut Rizka dan Suharyani (2015) lebih dominan pada program, meskipun demikian bentuk kemitraan dalam izin operasional lembaga menjadi salah satu hal yang pertama dan utama untuk mempertahankan eksistensi PKBM.

Bentuk kerjasama lainnya yaitu berupa perlindungan hukum oleh pemerintah desa kepada PKBM untuk menunjang program yang dijalankan. PKBM menurut Gunartin et al. (2018) membutuhkan pendanaan dari kegiatan bermitra untuk mendapatkan pendanaan yang maksimal. Salah satu strategi penting dalam peningkatan mutu pendidikan nonformal yaitu optimalisasi sarana, prasarana, serta bantuan modal usaha dari lembaga eksternal yang bekerja sama dengan lembaga pendidikan nonformal tersebut (Rosmaladewi et al., 2015). Pembinaan, pendampingan, dan motivasi merupakan bentuk kerjasama yang sangat penting diberikan oleh pemerintah desa kepada PKBM. Tujuan dari motivasi yang diberikan oleh pemerintah desa yaitu untuk meningkatkan partisipasi masyarakat dalam program pendidikan. Pemerintah desa menjadi stakeholder yang memiliki pengaruh signifikan untuk mengubah pola pikir masyarakat desa yang memandang tidak adanya korelasi antara pendidikan dengan tingkat kesejahteraan hidup. Oleh sebab itu, pemerintah desa memberikan gambaran program PKBM yang bersifat aplikatif dan dapat diterapkan pada masa kini untuk meningkatkan kesejahteraan masyarakat.

Pemerintah desa sebagai stakeholder memiliki peranan yang sangat penting dalam 
meningkatkan partisipasi masyarakat. Skema yang dirancang oleh pemerintah desa diantaranya yaitu penjangkauan masyarakat, intervensi, dan evaluasi. Penjangkauan masyarakat dilakukan dengan mengidentifikasi kebutuhan masyarakat. Kebutuhan masyarakat tersebut menjadi dasar bagi program kerjasama PKBM dan pemerintah desa agar tujuan yang diharapkan bisa tepat sasaran. Kebutuhan masyarakat merupakan modal awal untuk menarik minat masyarakat agar memiliki komitmen untuk berpartisipasi aktif. Penjangkauan masyarakat juga ditunjang dengan menghimpun dukungan dari tokoh masyarakat dan dukungan sosial. Intervensi dilakukan dengan membangun komitmen masyarakat dan secara konsisten mengembangkan minat sesuai kebutuhan masyarakat tersebut. Upaya PKBM dalam menghimpun partisipasi masyarakat dilakukan melalui dukungan tokoh masyarakat seperti Ketua Rukun Tetangga (Saputra \& Hati, 2017). PKBM juga memanfaatkan jaringan sosial untuk bekerja sama dalam upaya meningkatkan partisipasi masyarakat yang acuh terhadap pendidikan. Peningkatan partisipasi masyarakat sebagaimana dijelaskan oleh Mashudi (2016) diperlukan adanya sinergitas komunikasi, koordinasi, kemitraan, interaksi, dan kerjasama dengan lembaga eksternal seperti pemerintah, pelaku usaha, atau tokoh masyarakat. Hal tersebut membuat PKBM memiliki prospektif dalam meningkatkan sustainabilitas lembaganya.

Bentuk partisipasi oleh masyarakat ditunjukkan melalui partisipasi dalam perencanaan seperti proaktif dalam kegiatan identifikasi kebutuhan, menyumbang ide, masukan, dan saran untuk merencanakan program sesuai dengan kebutuhan. Partisipasi dalam pelaksanaan berupa komitmen untuk selalu turut serta menjadi warga belajar, mempertinggi angka kehadiran, dan antusiasme. Partisipasi dalam evaluasi berkaitan dengan peran warga belajar dalam menilai ketercapaian indikator dan tujuan belajar sebagai bahan pengembangan program selanjutnya. Hal tersebut dijadikan sebagai indikator keberhasilan program pendidikan yang berkelanjutan dan sepanjang hayat. Bentuk-bentuk partisipasi masyarakat dalam program-program PKBM menurut Saputra dan Hati (2017) yaitu partisipasi perencanaan program yang berhasil menstimulasi tokoh masyarakat untuk turut memberikan dukungan dan komitmen terhadap pelaksanaan program. Tahap selanjutnya dari kerjasama antara PKBM dengan pemerintah desa yaitu melakukan monitoring sebagai upaya mengadakan program belajar berkelanjutan, memiliki konsistensi, dan mencapai indikator keberhasilan. Monitoring kemitraan PKBM yang prospektif dikembangkan dengan konsep multi arah, sehingga dapat saling melengkapi, berkelanjutan, dan mencapai indikator keberhasilan berupa peningkatan mutu serta kepuasan kerjasama antar lembaga (Rizka \& Haryani, 2015). Monitoring dan evaluasi menurut Saputra dan Hati (2017) dilakukan sebagai upaya untuk mengetahui kemajuan dan pengembangan program sehingga dapat membantu lembaga memberikan perlakuan khusus bagi program yang tidak mencapai indikator keberhasilan.

Hak dan kewajiban kedua belah pihak merupakan suatu hal yang mempengaruhi indikator keberhasilan. Substansi hak dan kewajiban harus tertulis agar dapat menjelaskan batasan kewenangan antara kedua belah pihak. Pengaturan kerjasama yang tidak menggunakan perjanjian tertulis disebut handshake agreement (Sulistiyani, 2004). Hal tersebut harus tetap diimbangi dengan komitmen terkait pemenuhan dan upaya untuk meningkatkan partisipasi masyarakat dalam mengikuti serangkaian program-program yang telah dibuat PKBM

\section{Kendala yang Dihadapi oleh PKBM dan Pemerintah Desa dalam Meningkatkan Partisipasi Pendidikan Masyarakat}

Faktor penghambat kemitraan menjadi kendala yang sangat berpengaruh pada keberlanjutan dan pengembangan program lembaga. Terdapat dua kendala yang dihadapi oleh PKBM dengan pemerintah desa dalam menjalankan program kerjasama diantaranya yaitu kurangnya komitmen masyarakat dan sosialisasi program PKBM yang tidak optimal. Faktor penghambat kemitraan PKBM menurut Rizka dan Gustiana (2015) merupakan faktor yang berpengaruh pada perlambatan pembangunan program lembaga. Kurangnya kesadaran masyarakat menjadi faktor utama yang mampu menghambat gerak dalam mencapai tujuan pendidikan. Komitmen masyarakat untuk memperoleh dan menuntaskan pendidikan bersifat tidak tetap, bisa meningkat dan menurun. Masyarakat menganggap bahwa pendidikan tidak menjamin kesuksesan dan kemajuan bagi dirinya (Irawati, 2015). Hal tersebut yang membuat masyarakat merasa 
enggan untuk bersekolah atau melanjutkan pendidikan.

Masyarakat berantusias untuk turut serta dalam program belajar hanya pada awal periode, sedangkan menjelang akhir periode terjadi penurunan jumlah masyarakat yang mengikuti program belajar. Komitmen yang tidak stabil tersebut membuat program belajar yang direncanakan oleh PKBM dan pemerintah desa mengalami perlambatan dalam mencapai tujuan pendidikan. Komitmen tersebut juga dipengaruhi oleh kurangnya pengawasan pelaksanaan dan pendampingan program. Pemerintah desa sebagai stakeholder tidak dapat membagi tugas antara urusan pemerintahan dengan pembinaan warga belajar dalam PKBM. Jadwal yang saling tumpang tindih antara program dan kepentingan pribadi warga belajar juga turut berpengaruh pada komitmen masyarakat. Faktor utama penyebab kurangnya komitmen masyarakat dalam memperoleh pendidikan yaitu dipengaruhi oleh kepentingan mencari pekerjaan serabutan tanpa didasarkan pada keterampilan yang dimiliki. Hambatan upaya partisipasi masyarakat juga disebabkan adanya biaya pendaftaran untuk peserta program, sehingga menjadi pertimbangan bagi masyarakat untuk mengikuti program tersebut. Hal tersebut telah membuktikan bahwa masyarakat perlu mendapatkan pendampingan atau komunikasi aktif baik dari PKBM maupun pemerintah desa sebagai upaya meningkatkan partisipasi masyarakat dalam bidang pendidikan.

Permasalahan selanjutnya yaitu sosialisasi program PKBM yang belum optimal. Upaya PKBM dan pemerintah desa dalam meningkatkan partisipasi pendidikan masyarakat selalu membutuhkan aktor penggerak agar mampu menciptakan kondisi yang penuh motivasi. Aktor penggerak tersebut idealnya adalah kedua belah pihak yaitu pihak PKBM dan pemerintah desa. Pada kenyataannya kinerja dari pemerintah desa sebagai stakeholder dianggap kurang optimal. Pemerintah desa pada awal periode selalu memberikan sumbangsih yang optimal, sehingga mempengaruhi peningkatan partisipasi masyarakat secara signifikan. Semakin berjalannya program, pendampingan pemerintah desa menjadi kurang maksimal. Hal tersebut menjadi penghambat dalam proses pencapaian tujuan pendidikan yang berkelanjutan bagi lembaga pengelola. Sekolah harus bertanggung jawab terhadap perubahan masyarakat (Marzuki,
2009). Hal tersebut dapat dilakukan melalui fungsi layanan bimbingan, forum komunikasi antara sekolah dengan masyarakat. Partisipasi akan meningkat apabila hasil dari suatu program dapat diperkirakan dan dipastikan berhasil, dan program akan dinyatakan gagal apabila tidak dapat memberikan jaminan hidup yang jelas. Tujuan kerjasama harus berpedoman pada prinsip kesamaan visi, misi, dan program guna menunjang tujuan organisasi menjadi fundamen untuk meningkatkan motivasi dalam membangun kerjasama (Direktorat Pembinaan Pendidikan Masyarakat, 2012). Oleh karena itu, PKBM dan pemerintah desa perlu bersinergi dengan menyamakan visi misi dalam mensosialisasikan berbagai program yang telah dilaksanakan sesuai dengan akad kerjasama yang disepakati, sehingga upaya meningkatkan partisipasi masyarakat dalam bidang pendidikan bisa terwujud.

\section{Upaya PKBM dan Pemerintah Desa untuk Mengatasi Kendala dalam Meningkatkan Partisipasi Pendidikan Masyarakat}

Upaya PKBM dan pemerintah desa untuk mengatasi kendala dalam meningkatkan partisipasi pendidikan masyarakat dilakukan dengan membangun komitmen masyarakat dan mensosialisasikan berbagai program yang dijalankan oleh lembaga. Bermitra dengan instansi pemerintah bukan kegiatan yang mudah, karena diperlukan sebuah strategi yang efektif agar hubungan kemitraan tersebut dapat terjalin dengan baik (Rizka \& Gustiana, 2015). Strategi kemitraan unjuk kerja dan kinerja menjadi solusi yang diterapkan untuk mempertahankan relasi agar tetap terjaga. PKBM membuat proposal dan melakukan komunikasi dengan pemerintah desa untuk menyamakan persepsi mengenai program yang akan dijalankan. PKBM memberikan opsi-opsi program dengan masukan-masukan dari pemerintah desa, sehingga pihak kedua menjadi lebih tertarik untuk melanjutkan kemitraan. Peningkatan kinerja pengelola PKBM juga menjadi solusi dalam mempertahankan kemitraan dengan pemerintah desa. Kedua belah pihak pada akhirnya mempunyai kekuatan untuk saling tarik menarik dalam memajukan program pendidikan.

Pemerintah desa dalam proses membangun komitmen masyarakat melakukan komunikasi aktif dan memotivasi warga masyarakat untuk terus melanjutkan pendidikan agar memiliki pengetahuan dan keterampilan sebagai continuing- 
learning. Hal tersebut didasarkan pada UndangUndang Republik Indonesia Nomor 20 Tahun 2003 tentang Sistem Pendidikan Nasional Pasal 1 dan 5. Pasal tersebut menjelaskan bahwa setiap warga negara mempunyai hak dan kesempatan yang sama untuk memperoleh pendidikan yang bermutu. Pemerintah desa juga melakukan komunikasi aktif dan memotivasi masyarakat melalui berbagai acara yang diadakan oleh pemerintah desa terutama yang berkaitan tentang pentingnya pendidikan. Hal tersebut tidak terlepas dari rendahnya tingkat pendidikan masyarakat yang ada di wilayah pedesaan, sehingga dalam Undang-Undang Nomor 6 Tahun 2014 Pasal 26 ayat (1) menyatakan bahwa kepala desa memiliki tugas untuk melakukan pemberdayaan masyarakat desa.

Upaya meningkatkan pendidikan masyarakat desa tidak semata-mata dilakukan oleh pemerintah desa, namun PKBM juga turut memberikan kontribusi. Hal tersebut sejalan dengan pendapat Septiani (2015) bahwa dalam proses pengembangan program perlu melibatkan dan memanfaatkan potensi masyarakat. Potensi yang ada di masyarakat perlu digali, ditumbuhkan, dan dimanfaatkan melalui pendekatan persuasif. Program yang dilaksanakan harus berdasarkan pengembangan pengetahuan dan keterampilan yang ada di masyarakat, sehingga akan berdampak pada pengetahuan dan ekonomi keluarga. Upaya mengatasi kendala sosialisasi program PKBM yang belum optimal dilakukan dengan memberikan santunan kepada anak yatim piatu, memberikan buku-buku bacaan gratis kepada masyarakat, serta memberikan bantuan sembako kepada masyarakat miskin. Kegiatan ini dilakukan setiap setahun sekali bertepatan dengan tahun ajaran baru, sehingga program PKBM yang meliputi kejar paket, pendidikan kewirausahaan, dan taman bacaan masyarakat sebagai upaya meningkatkan partisipasi masyarakat di bidang pendidikan dapat terwujud.

\section{SIMPULAN}

Strategi yang digunakan oleh PKBM dalam mengembangkan program pendidikan nonformal dilakukan melalui identifikasi masyarakat, program, dan kemitraan. Identifikasi masyarakat bertujuan untuk memperoleh gambaran nyata dari kebutuhan masyarakat untuk mengembangkan strategi program. Strategi kemitraan dilakukan dengan mengadakan kerjasama dengan pemerintah desa. Proses yang dilakukan dalam membangun kerjasama dalam upaya meningkatkan partisipasi masyarakat yaitu dengan membuat akad kerjasama, melaksanakan program kerjasama, dan melakukan monitoring. Program yang dilaksanakan dalam PKBM berupa program kesetaraan, pendidikan kewirausahaan, taman baca, dan pelestarian budaya setempat. Pola kerjasama yang dilakukan yaitu pendampingan dan pembinaan, dengan bentuk kerjasama berupa dukungan regulasi kebijakan, perlindungan hukum, bantuan anggaran, pendampingan, pembinaan, dan motivasi kepada masyarakat. Skema peningkatan partisipasi masyarakat terhadap pendidikan yang dilakukan oleh pemerintah desa yaitu penjangkauan masyarakat, intervensi, dan evaluasi. PKBM menghadapi beberapa kendala dalam upaya meningkatkan partisipasi masyarakat yaitu berupa menurunnya komitmen masyarakat dan sosialisasi program yang kurang optimal. Upaya yang dilakukan untuk mengatasi kendala tersebut yaitu dengan melakukan inovasi sosialisasi oleh pemerintah desa serta strategi unjuk kerja yang dilakukan oleh pengelola PKBM.

\section{DAFTAR RUJUKAN}

Ardilah, T., Makmur, \& Hanafi. (2002). Upaya Kepala Desa untuk Meningkatkan Partisipasi Masyarakat dalam Pembangunan Desa: Studi di Desa Bareng Kabupaten Jombang. Jurnal Administrasi Publik, 2(1), 71-77.

Badan Akreditasi PAUD dan PNF. (2019). Konsep Dasar Pendidikan Non Formal: PKBM dan LKP. Jakarta: Dirjen Dikdasmen Kemendikbud.

Direktorat Pembinaan Pendidikan Masyarakat. (2012). Standar dan Prosedur Penyelenggaraan Pusat Kegiatan Belajar Masyarakat. Jakarta: Dirjen PAUD dan PNF.

Gunartin. et al. (2018). Pusat Kegiatan Belajar Masyarakat sebagai Tempat Alternatif Menumbuhkan Kemandirian Wirausaha Warga Belajar: Studi PKBM Insan Karya Pamulang Tangerang. Jurnal Pendidikan Ekonomi dan Bisnis, 3(2), 30-49.

Ibrahim, A. et al. (2018). Pemberdayaan Masyarakat melalui PKBM untuk Meningkatkan Keterampilan Masyarakat Miskin. Jurnal Pengembangan Masyarakat Islam, 3(1), 1-24.

Irawati, F. (2015). Pemberdayaan Masyarakat 
melalui Pusat Kegiatan Belajar Masyarakat (PKBM) Pinilih di Desa Gumpang Kecamatan Kartasura Kabupaten Sukoharjo. Jurnal Ilmiah Pendidikan Sosiologi-Antropologi, 5(2), 180-200.

Irwan, et al. (2016). Strategi Peningkatan Peran

PKBM dalam Meningkatkan Kecakapan

Hidup Masyarakat melalui Pendampingan

Berbasis Kearifan Lokal di PKBM Provinsi

Banten. Jurnal Untirta, 1(2), 121-128.

Kamil, M. (2010). Strategi Kemitraan dalam Membangun PNF melalui Pemberdayaan Masyarakat. Bandung: Depdiknas Penelitian dan Pengembangan.

Kaufman, R. \& Mayer. (2013). Encyclopedia of Terminology for Educational Communications and Technology. New York: Springer.

Marzuki, S. (2009). Dimensi-Dimensi Pendidikan Non Formal. Malang: Fajar Publisher.

Mashudi, M. I. (2016). Sinergi Masyarakat dan PKBM. Journal UNESA, 1(1), 1-7.

Oktiwanti, L. et al. (2016). Model Pengembangan Kemitraan Pendidikan Non Formal dan Informal dengan Corporate Social Responsibility dalam Memberdayakan Masyarakat. Jurnal Cendekiawan Ilmiah PLS, 1(1), 40-52.

Republik Indonesia. (2003). Undang-Undang Nomor 20 Tahun 2003 tentang Sistem Pendidikan Nasional. Lembaran Negara Republik Indonesia Tahun 2003 Nomor 78.

Republik Indonesia. (2014). Undang-Undang Nomor 6 Tahun 2014 tentang Desa. Lembaran Negara Republik Indonesia Tahun 2003 Nomor 7.

Rizka, M. A. \& Gustiana, D. (2015). Strategi Kemitraan Penyelenggaraan Program Pendidikan Non Formal: Studi Kasus pada Pusat Kegiatan Belajar Masyarakat Terampil.
Jurnal Kependidikan, 14(2), 169-178.

Rizka, M. A. \& Suharyani. (2015). Pola Kemitraan Pusat Kegiatan Belajar Masyarakat (PKBM) bagi Keberlanjutan Program Pendidikan Non Formal. Jurnal Kependidikan, 14(3), 239-249.

Rosmaladewi, O. et al. (2015). Implementasi Model Pendidikan Non Formal Berbasis Keterampilan Agribisnis di Pusat Kegiatan Belajar Masyarakat Gita Gemilang dan PKBM Suka Rakyat Kabupaten Garut. Jurnal Pengabdian Kepada Masyarakat, 7(2), 92-107

Saputra, F. A. \& Hati, G. (2017). Upaya Peningkatan Partisipasi dalam Program Pengembangan Masyarakat: Studi Deskriptif Upaya Pusat Kegiatan Belajar Mengajar Kampung Cerdas Indonesia dalam Meningkatkan Partisipasi Masyarakat di Kelurahan Curug, Cimanggis, Depok. Jurnal Ilmu Kesejahteraan Sosial, 18(1), 59-78.

Septiani, M. (2015). Pengalaman Pusat Kegiatan Belajar Masyarakat (PKBM) dalam Memfasilitasi Masyarakat Belajar Sepanjang Hayat. Jurnal Ilmiah VISI PPTK PAUDNI, 10(2), 67-77.

Sudjana, D. (2001). Pendidikan Luar Sekolah. Bandung: Falah Production.

Sulistiyani, A. T. (2004). Kemitraan dan ModelModel Pemberdayaan. Yogyakarta: Gava Media.

Syamsuri, S. \& Ulfah, S. M. (2019). Implementasi Kebijakan Model Kerjasama Pendidikan Kesetaraan dalam Meningkatkan Pembangunan Sumber Daya Manusia. Palangka Raya: Universitas Palangka Raya.

Yin, R. K. (2006). Penelitian Studi Kasus: Desain dan Metode. Jakarta: Raja Grafindo Persada. 